\title{
A FIVE-YEAR STUDY ON THE HEAVY-METAL POLLUTION OF GUANABARA BAY SEDIMENTS (RIO DE JANEIRO, BRAZIL) AND EVALUATION OF THE METAL BIOAVAILABILITY BY MEANS OF GEOCHEMICAL SPECIATION
}

\author{
G. PERIN ${ }^{\otimes} 1 *$, R. FABRIS ${ }^{1}$, S. MANENTE', A. REBELLO WAGENER ${ }^{2}$, \\ C. HAMACHER ${ }^{2}$ and S. SCOTTO' \\ 'Ca'Foscari University of Venice, Dept. Environmental Sciences, Dorsoduro 2137 Venezia, Italy; and \\ ${ }_{2}$ Pontificia Universidade Catolica de Rio de Janeiro (PUC), Rio de Janeiro, Brazil
}

(Received January 1996; accepted in revised form April 1997)

\begin{abstract}
Surface sediments of the Guanabara Bay (Rio de Janeiro, Brazil) were analyzed by a sequential extraction procedure for $\mathrm{Cd}, \mathrm{Cr}, \mathrm{Cu}, \mathrm{Pb}, \mathrm{Zn}, \mathrm{Mn}$ and $\mathrm{Fe}$, determining their distribution among five geochemical phases and in the nitric acid extractable phase. Bioavailable phases and non-bioavailable phases have been determined in six transects in the bay to define the significant level of pollution due to sediment metal contamination. A multiple correlation showed limited responsibility of $\mathrm{Mn}$ and $\mathrm{Fe}$ oxides and humic acids in the adsorption process, which allowed discrimination among the different processes and suggested the strong influence of the hydrogen sulfide present in the highly reduced bay bottom environment. The authors suggest the need to avoid disturbing bottom sediment by dredging or by artificial bottom aeration which could result in a rapid worsening of the environment due to the accelerated formation of more soluble oxygenated metal compounds making the toxic metals much more available to the benthic fauna and to the bay biota in general. (C) 1997 Elsevier Science Ltd
\end{abstract}

Key words-sediments, heavy metals, sequential extraction, metal bioavailability, iron and manganese oxides

\section{INTRODUCTION}

This research is a five-year investigation to evaluate the bioavailability of the toxics buried in the surficial sediments in a tropical environment. The main aim is to identify the care needed in cleaning very polluted water bodies without disturbing the delicate ecosystem. This paper reports the results of the research done in the Baia de Guanabara (Rio de Janeiro, Brazil) regarding the bioavailability and the dynamics of heavy metals. The role of $\mathrm{Mn}$ and $\mathrm{Fe}$ oxides/hydroxides was analyzed and, indirectly, that of the hydrogen sulfide in metal distribution and release.

Heavy metals are widely spread in the water environment, and the sediment, being their final fate in the water bodies, has been investigated frequently for the metal content. Usually, only the total metal is determined in the sediments, giving only a rough approach to the understanding the role of metals as pollutants in ecotoxicology because, normally, there bioavailability is not considered. It is well known that water pollutants, sinking on the sediments, can be bonded to the inorganic/organic matrices by adsorption processes; the intensity can be predicted by many ecotoxicological constants (e.g. $K_{\mathrm{d}}$ or partition coefficient of the compound between sediment and water, $K_{\times}$or the $K_{\mathrm{d}}$ corrected for the organic carbon content) (Schwarzenbach et al., 1993). For metals, the main processes are the co-precipitation and the co-reaction with oxides and hydroxides of manganese and iron, humic acids, sulfides and clays (Foerstner and Wittmann, 1981; Schoer, 1985; Belzile et al., 1989).

These processes may occur at the same time or they may develop successively on the grain coatings of the sediment. In some cases, one may prevail over the others, depending on environmental conditions of $\mathrm{pH}$, redox potential, oxygen availability, etc.

Metal availability depends on the strongest adsorber/ligand; in a complex system like polluted sediments, the roles played by the $\mathrm{Mn}$ and Fe oxides, clay structures, humic acids, the most important geochemical matrices in an environment similar to the one studied, and sulfide are not easily defined. There is a strong partition competition in terms of $K_{\mathrm{d}}$ among different surfaces ( $\mathrm{Mn}$ and $\mathrm{Fe}$ oxides, high molecular weight humic acids, clays) and a ligand competition among the same structures and the 
sulfide ions. Because the partition seems to take place in a few days, therefore relatively rapidly, one could consider the first process (partition) very close to an equilibrium at a first approximation.

Each geochemical phase (GPH) seems to have different adsorption constants, as reported by Oakley et al. (1981). Hydrous Mn oxides exhibit more extensive isomorphic substitution than amorphous $\mathrm{Fe}$ oxides and, therefore, show conditional equilibrium contants (for $\mathrm{Cu}$ and $\mathrm{Cd}$ ) of one or two orders as compared to those of bentonite clay, $\mathrm{Fe}$ oxides or humic acids. Despite the relative small amount normally present in the sediment (Oakley et al., 1981) Mn oxide plays an important role in metal adsorption. However, in the case of very anoxic sediments, hydrogen sulfide could be the main determining factor because of the very low solubility constants $\left(K_{\mathrm{so}}\right)$ of the sulfide of the more important heavy metals involved in sediment pollution. Therefore, a strong competition is expected to exist among the involved parameters.

The purpose of the research has been, therefore, the determination of the factors involved in metal sinking in the Brazilian-tropical water body in order to get information on environmental risks during the possible recovery of those environments using standard techniques such as bottom dredging or deep aeration.

\section{MATERIALS AND METHODS}

\section{Characteristics of the case studies}

Guanabara Bay can be considered as an estuary of $380 \mathrm{~km}^{2}$ between the cities of Rio de Janeiro and Niteroi, located in the center of the metropolitan region of Rio de Janeiro, with a population of more than 8 million. The bay receives 91 tributaries and its drainage basin (about $11,000 \mathrm{~km}^{2}$ ) has a water flow of $150 \mathrm{~m}^{3} / \mathrm{s}$ with an exchange rate of about $10 \%$ with the ocean. Originally, the ecosystem of the bay was a mangrove forest with mud flats and banks. Nowadays, the mangrove forest has almost completely disappeared. Many industries are located in the bay area. Special emphasis must be given to the two oil refineries and to the many shipyards mostly in the north-east region. Due to intensive port activities, connected with the oil industry, oil spills are a frequent problem as well as tank cleanings in the bay. The industrial discharges of sewage and process wastes represent a principal source of pollution of the bay waters and can account for $25 \%$ of the organic pollution and more than $90 \%$ of the chemical pollution. The bay is the receptacle tank of about $18 \mathrm{~m}^{3} / \mathrm{s}$ of domestic sewage, with a secondary treatment made on only $25 \%$ of the total. Large amounts of metals arrive into the bay through the rivers (Rego et al., 1993).

At the water surface, Guanabara Bay has a very high oxygen level, sometimes up to $300 \%$ of saturation due to the high primary productivity according to the high nutrient level and the tropical constant high temperature and availability of light. At the bottom $(3-19 \mathrm{~m})$, the dissolved oxygen is close to zero. Sedimentation rates appear to be high in recent years (Moreira and Godoy, 1988) ranging around $0.15 \mathrm{~cm} / \mathrm{yr}$ until 1950 and then suddenly increasing to about $1.3 \mathrm{~cm} / \mathrm{yr}$.

The sediment heavy metal pollution in the bay has been studied by De Luca Rebello et al. (1986). The researches of De Souza et al. (1986) and Perin et al. (1993) dealt with the geochemical speciation in some areas of the bay, giving a preliminary frame of the main pollution sources.

\section{Sampling and analyses}

The sampling points have been chosen along the main currents in the bay along six transects, as shown in Fig. 1.

The samplings were done along transects which follow the main tidal currents in the bay and are divided into the main transect (or number 1) and branch transects (from number 2 to number 6), in order to show the influence of the nearshore discharges. Each branch transect ends in the main transect.

The main transect starts in the more internal western part of the bay rounding the Ilha do Governador (International Airport), crosses the whole bay along the main current direction and ends in front of Copacabana beach receiving, along its way, the other transects. Transect 2 has been settled in the North, in the very internal part of the bay beyond the Paqueta' isle. Transect 3 is located close to the eastern part of the bay receiving the waters of the Rio Guapirim, Guarai', Guarai-Mirim and Guaxindiba until Sete Pontos and Neves, meeting the main transect in Station 14. Transect 4 controls the sediments between the Ilha do Fundão until the Ilha Sta. Cruz. Transect 5 monitors sediment quality in the area below the Presidente Costa and Silva bridge, along the coast of Ilha das Cobras and the Santos Dumont Airport. Finally, transect 6 controls the Niteroi Bay (Enseada do Saco São Francisco and Enseada de Jurujuba).

Samples were taken with a Petersen dredge, getting the first $40 \mathrm{~cm}$ of surficial sediment (representing, therefore, the last $30-35$ years of sedimentation), carefully screened for determining the presence of animals and for checking the color, the structure and the smell, then put in glass jars and frozen. Depending on the bottom structure, each station was sampled several times (minimum three) to get a representative sample obtained by carefully mixing the different sub-samples. Sixty-one stations were determined in the bay during the 10 campaigns (1991-1995) and 51 used for the transect analysis.

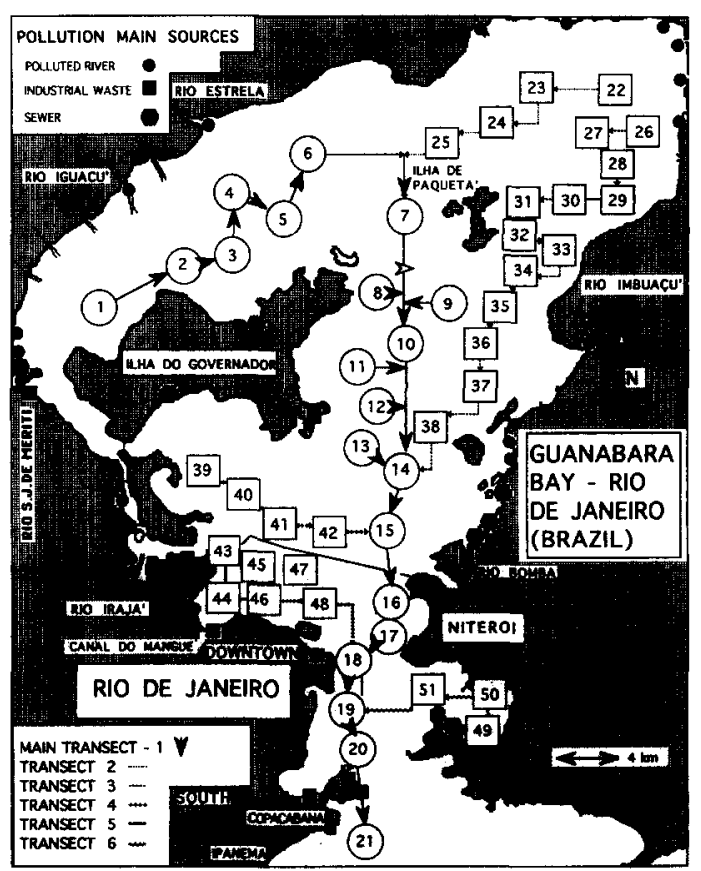

Fig. 1. Guanabara Bay-sampling stations, transects and pollution sources. 
The sequential extraction procedure was a slightly modified version of the technique as proposed by Chester and Hughes (1967) and Tessier et al. (1979). Recent papers confirmed the soundness of the method (Sager, 1989; Rubio et al., 1993). The five GPHs obtained have the same meanings as in Chen et al. (1976): i.e. phase 1, ion-exchangeable metal; phase 2 , metal bonded to carbonates; phase 3. easily-reducible metal (bonded to oxides of manganese and non-crystalline lattice iron); phase 4 , metal bonded to organics and sulfides; phase 5 , reducible metal (bonded to iron oxides) remaining after the coating destruction by oxidative treatment of phase 4 . Total metal content was determined in two different ways: by hot nitric acid treatment (anthropogenic phase) and by $\mathrm{HF}+\mathrm{HNO}_{3}$ dissolution in a Teflon container. The geochemical phases were called GPHs, indicating with a number the extraction step. The suffixes $\mathrm{HNO}_{3}$ or a and $\mathrm{HF}$ or $\mathrm{b}$ indicate the geochemical phases obtained by treatment with nitric acid and with hydrofluoric acid in a sealed Teflon container ("bomb").

The GPHs were determined as follows. Ten grams of dry sediment was treated with $40 \mathrm{ml}$ of $1 \mathrm{M} \mathrm{NH} \mathrm{H}_{4} \mathrm{OH}$, shaken for $1 \mathrm{~h}$, settled overnight, filtered with $0.45-\mu \mathrm{m}$ filter, washed three times with distilled water metal-free; the residue (1) was dried overnight at $105^{\circ} \mathrm{C}$. This solution contained the first GPH. Three grams of the residue (1) was mixed with $40 \mathrm{ml}$ of $1 \mathrm{M} \mathrm{NaOAc}$ plus $1 \mathrm{ml}$ of HAc, shaken for $2 \mathrm{~h}$, settled for two nights, filtered and washed. This solution contained the second GPH. The residue (2) was dried overnight like residue (1). All the residue (2) was mixed with $40 \mathrm{ml} \mathrm{NH}{ }_{2} \mathrm{OH} \cdot \mathrm{HCl}$ in $0.01 \mathrm{M} \mathrm{HNO}_{3}$, shaken for $45 \mathrm{~min}$, settled for two nights, filtered and washed. This solution contained the third GPH. The residue (3) was dried overnight like residue (1). All the residue (3), treated with $6 \mathrm{ml}$ of $0.02 \mathrm{M} \mathrm{HNO}_{3}$ plus $10 \mathrm{ml}$ of $30 \% \mathrm{H}_{2} \mathrm{O}_{2}$, was acidified with $\mathrm{HNO}_{3}$ at $\mathrm{pH} 2$, heated to $75^{\circ} \mathrm{C}$ for $2 \mathrm{~h}$ and mixed with $30 \% \mathrm{H}_{2} \mathrm{O}_{2}$ at $\mathrm{pH}$ 2. The mixture was heated for $4 \mathrm{~h}$ in an oven. After cooling, it was mixed together with $15 \mathrm{ml}$ of $3.2 \mathrm{M} \mathrm{NH} \mathrm{NHAc}_{4}$ in $20 \%(\mathrm{v} / \mathrm{v}) \mathrm{HNO}_{3}$, and settled for two nights. This cleared solution contained the fourth GPH. The residue (4), washed accurately, was dried in an oven overnight like residue (1). Finally, the residue (4) was mixed with $40 \mathrm{ml}$ of $0.04 \mathrm{M} \mathrm{N} \mathrm{N}_{2} \mathrm{OH} \cdot \mathrm{HCl}$ in $25 \% \mathrm{HAc}$, heated to $98^{\circ} \mathrm{C}$ for $5 \mathrm{~h}$, settled for two nights and filtered. This solution contained the fifth GPH. For the determination of the total anthropogenic metal content, $10 \mathrm{~g}$ of the original sediment was treated with $\mathrm{HNO}_{3}$ conc. at $150^{\circ} \mathrm{C}$ in a Teflon container sealed with a Tefion cap (Teflon Bomb) in an oven, mixed with enough $\mathrm{H}_{2} \mathrm{O}_{2}$ to eliminate the $\mathrm{N}_{2} \mathrm{O}_{4}$ vapors and diluted to $100 \mathrm{ml}$. For HF total metal content, $0.5 \mathrm{~g}$ of dry sediment was treated in a Teflon container sealed with a Teflon cap (Teflon Bomb) in an oven with $0.5 \mathrm{ml}$ of distilled water, $1.5 \mathrm{ml}$ of concentrated $\mathrm{HF}$ and $3.0 \mathrm{ml}$ of aqua regia ( $\mathrm{HCl}$ conc. $+\mathrm{HNO}_{3}, 3: 1$ ). All the solutions were examined by flame atomic absorption analysis (Spectra AA 250 plus, Varian).

The high concentration of hydrogen sulfide in the bay sediments prevented a correct quantitative analysis of the free sulfide because, cespite of the very careful samplings, the sample loses $\mathrm{H}_{2} \mathrm{~S}$ during the sampling and the storage. Because the $\mathrm{H}_{2} \mathrm{~S}$ content varies between 0.01 and $0.53 \mathrm{~mol} / \mathrm{kg}$ for the wet sediment, as acid volatile sulfide determined according to DiToro et al. (1992), to avoid sulfide doubtful analyses, a regression analysis was preferred to get a correlation matrix for the five more important metals $(\mathrm{Cr}, \mathrm{Cu}, \mathrm{Ni}, \mathrm{Pb}, \mathrm{Zn})$ and the different forms of $\mathrm{Fe}$ and $\mathrm{Mn}$ present as ligands in the sediment. In such a way, the authors tried to give account, indirectly, of the sulfide role. Volatile solids (VS, humic acids indicators) also has been included in the matrix. Data on the clay distribution have not been included because former research done by Marabini et al. (1994) showed in the internal and in the central part of the bay an homogenous presence of pelite.
For a comparison of pollution levels in Guanabara Bay with a former investigation in other water (Foerstner and Wittmann, 1981), the analytical data have been treated summing the results from the first, second and third GPHs to get the bio-available phase (BAP) and from the fourth and fifth to obtain the non-bioavailable phase (NBAP). This procedure improves the metal immediate bioavailable (MIBA) sediment classification proposed in a former paper (Perin et al., 1993) where only the first and second GPHs were used as bioavailability criteria. As shown by Perin $e t$ al. (1986) in carbonate-rich sediments, a large amount of carbonate is again present in the third GPH and, therefore, it must be taken into account. From now on the metals will be identified as BAP and NBAP depending if they are included in the $\Sigma$ GPH $1,2,3$ or $\Sigma G P H ~ 4,5$ (sum of the values of the geochemical phases 1,2 and 3 or 4 and 5 , respectively).

\section{RESULTS}

The results of the investigations are shown in Tables 1, 2 and 3 and in Figs 2-5. Figures 2 and 3 describe the behavior of $\mathrm{Zn}, \mathrm{Mn}, \mathrm{Cr}, \mathrm{Cu}, \mathrm{Ni}$ and $\mathrm{Pb}$ along the main transect (Transect 1 ) from the internal part of the bay until the estuary gateway as BAPs. Figures 4 and 5 show the same metals but as NBAPs. Table 1 shows the results of investigation on transects $2,3,4,5$ and 6 . Table 2 displays the descriptive statistical analysis of the sediment metal distribution in the different GPHs and the values of the VS. In some GPHs the values were below the instrumental detection limit or scarcely significant and, therefore, have been not considered in the table. Due to the extremely low concentration of $\mathrm{Cd}$ (mostly below the instrumental detection limit) the GPHs values are not reported here but its concentration will be discussed later in terms of total $\mathrm{HNO}_{3}$-extractable metal (Table 4), when the risk level classification of the Guanabara sediments will be considered. For the purpose of defining quality limits for sediments, the authors tried to prepare a reference table, combining and extrapolating the values of the sediment partition approach (SPA) (Chapman, 1989; Jonkers and Everts, 1992; Webster and Ridgway, 1994; Chapman et al., 1996) with the dredged sediment land disposal criteria (Ontario Ministry of Environment, 1988). One more level was included to get a more detailed classification between the no-risk level and the maximum-risk level (MRL) as reported by Jonkers and Everts (1992). The present authors are aware this kind of classification could not be perfect because SPA is more significant in the organic partition equilibria, but it could be a reference point simple and easy to be used. According to Table 3, a final Table 4 has been prepared showing the percentage of Guanabara Bay sediments in the specific risk level.

Multiple regression analysis matrices (Table 5) show the correlation coefficients among the different metals in the different phases regressed also to $\mathrm{Fe}$ and $\mathrm{Mn}$ extracted by the Teflon Bomb procedure (i.e. dissolved in HF). Table 6 shows the correlations among the $\mathrm{HNO}_{3}$-extracted metals (anthropogenic phase) and the HF-extracted $\mathrm{Fe}$ and $\mathrm{Mn}$. Both 
Table 1. Sum of the GPHs in the transects $2,3,4,5$ and $6(\mathrm{mg} / \mathrm{kg} \mathrm{d.w}$ )

\begin{tabular}{|c|c|c|c|c|c|c|c|c|c|c|c|c|}
\hline \multirow[b]{2}{*}{ Station } & \multicolumn{3}{|c|}{ Sum of GPHs 1,2 and 3} & \multicolumn{9}{|c|}{ Sum of GPHs 4 and 5} \\
\hline & $\mathrm{Cr}$ & $\mathrm{Cu}$ & $\mathrm{Ni}$ & $\mathrm{Pb}$ & $\mathrm{Zn}$ & $\mathrm{Mn}$ & $\mathrm{Cr}$ & $\mathrm{Cu}$ & $\mathrm{Ni}$ & $\mathrm{Pb}$ & $\mathrm{Zn}$ & Mn \\
\hline \multicolumn{13}{|c|}{ Transect 2} \\
\hline 22 & $<\mathrm{d} l$ & $<\mathrm{dl}$ & $<\mathrm{dl}$ & $<\mathrm{dl}$ & 154.4 & 305.9 & 17.0 & 40.2 & $<\mathrm{dl}$ & $<\mathrm{dl}$ & 272.1 & 75.4 \\
\hline 23 & $<\mathrm{dl}$ & $<\mathrm{dl}$ & $<\mathrm{dl}$ & $<\mathrm{dl}$ & 192.9 & 274.5 & 24.1 & 18.4 & 8.5 & 17.1 & 81.6 & 260.9 \\
\hline 24 & $<\mathrm{d} l$ & $<\mathrm{dl}$ & $<\mathrm{dl}$ & $<\mathrm{dl}$ & 146.1 & 510.5 & 35.7 & 18.9 & 9.7 & 25.7 & 243.6 & 441.5 \\
\hline 25 & $<\mathrm{dl}$ & $<\mathrm{dl}$ & $<\mathrm{dl}$ & $<\mathrm{dl}$ & 176.1 & 370.2 & 70.3 & 45.4 & 14.6 & 32.5 & 377.5 & 312.1 \\
\hline 7 & $<\mathrm{dl}$ & $<\mathrm{dl}$ & $<\mathrm{dl}$ & $<\mathrm{dl}$ & 85.0 & 264.4 & 72.2 & 23.4 & 10.8 & 32.8 & 139.6 & 295.0 \\
\hline \multicolumn{13}{|c|}{ Transect 3} \\
\hline 26 & $<\mathrm{dl}$ & $<\mathrm{dl}$ & 9.56 & $<\mathrm{dl}$ & 104.6 & 167.4 & 9.1 & 13.4 & $<$ dl & $<\mathrm{dl}$ & 57.2 & 89.6 \\
\hline 27 & $<\mathrm{dl}$ & $<\mathrm{dl}$ & $<\mathrm{dl}$ & $<\mathrm{dl}$ & 85.92 & 275.7 & 16.0 & 14.1 & 12.1 & 19.4 & 79.3 & 364.2 \\
\hline 28 & $<$ dl & $<\mathrm{dl}$ & 8.44 & $<\mathrm{dl}$ & 102.57 & 295.1 & 15.8 & 11.4 & 9.3 & 18.3 & 89.9 & 318.1 \\
\hline 29 & $<\mathrm{dl}$ & $<\mathrm{dl}$ & 8.67 & $<\mathrm{dl}$ & 105.21 & 441.8 & 17.2 & 12.7 & 7.3 & 14.6 & 60.2 & 272.3 \\
\hline 30 & $<\mathrm{dl}$ & $<\mathrm{dl}$ & 3.31 & $<\mathrm{dl}$ & 39.26 & 258.2 & 16.9 & 8.1 & 5.7 & 29.4 & 68.4 & 177.7 \\
\hline 31 & $<\mathrm{dl}$ & $<\mathrm{dl}$ & $<\mathrm{dl}$ & $<\mathrm{dl}$ & 73.72 & 276.6 & 19.9 & 10.5 & 9.7 & 29.2 & 90.6 & 276.5 \\
\hline 32 & $<\mathrm{dl}$ & $<\mathrm{dl}$ & $<\mathrm{dl}$ & $<\mathrm{dl}$ & 74.66 & 566.3 & 22.4 & 21.8 & 10.3 & 34.2 & 100.9 & 441.7 \\
\hline 33 & $<\mathrm{dl}$ & $<\mathrm{dl}$ & 8.54 & $<\mathrm{dl}$ & 128.55 & 853.0 & 27.2 & 17.4 & 10.0 & 27.4 & 203.2 & 339.2 \\
\hline 34 & $<\mathrm{dl}$ & $<\mathrm{dl}$ & $<\mathrm{dl}$ & $<\mathrm{dl}$ & 94.4 & 356.0 & 32.9 & 19.5 & 13.2 & 40.2 & 336.8 & 381.4 \\
\hline 35 & $<\mathrm{dl}$ & $<\mathrm{dl}$ & 0.99 & $<\mathrm{dl}$ & 3.97 & 15.7 & 18.7 & 6.33 & 7.5 & 21.8 & 97.7 & 167.9 \\
\hline 36 & $<\mathrm{dl}$ & $<\mathrm{dl}$ & $<\mathrm{dl}$ & $<\mathrm{dl}$ & 1.46 & 9.6 & 1.0 & $<\mathrm{dl}$ & 3.7 & 23.0 & 94.3 & 19.7 \\
\hline 37 & $<\mathrm{dl}$ & $<\mathrm{dl}$ & $<\mathrm{dl}$ & $<\mathrm{dl}$ & 174.84 & 340.7 & 18.7 & 17.4 & 6.3 & 21.0 & 193.4 & 133.0 \\
\hline 38 & $<$ dl & $<\mathrm{dl}$ & $<\mathrm{dl}$ & $<\mathrm{dl}$ & 120.98 & 405.5 & 22.0 & 32.6 & 8.1 & 32.9 & 106.3 & 258.9 \\
\hline 14 & $<\mathrm{dl}$ & $<\mathrm{dl}$ & $<\mathrm{dl}$ & $<\mathrm{dl}$ & 1.23 & 10.1 & 2.7 & 2.49 & 16.0 & 67.2 & 8.2 & 61.9 \\
\hline 15 & $<\mathrm{dl}$ & $<\mathrm{dl}$ & 6.75 & $<\mathrm{dl}$ & 133.54 & 275.2 & 25.1 & 43.3 & 8.4 & 41.7 & 199.5 & 166.1 \\
\hline \multicolumn{13}{|c|}{ Transect 4} \\
\hline 39 & 47.4 & $<\mathrm{dl}$ & $<\mathrm{dl}$ & $<\mathrm{dl}$ & 214.1 & 185.2 & 46.3 & 58.3 & 14.2 & 73.2 & 308.2 & 393.9 \\
\hline 40 & 28.6 & $<\mathrm{dl}$ & $<\mathrm{dl}$ & 13.9 & 181.5 & 117.7 & 34.8 & 54.3 & 8.9 & 59.2 & 202.2 & 198.9 \\
\hline 41 & 19.9 & $<\mathrm{dl}$ & $<\mathrm{dl}$ & 7.3 & 126.8 & 44.9 & 23.1 & 34.8 & 6.3 & 37.0 & 73.0 & 84.2 \\
\hline 42 & 17.4 & $<\mathrm{dl}$ & $<\mathrm{dl}$ & 8.7 & 97.4 & 110.4 & 17.4 & 18.6 & 5.5 & 31.8 & 60.6 & 64.4 \\
\hline 15 & $<\mathrm{dl}$ & $<\mathrm{dl}$ & 6.8 & $<\mathrm{dl}$ & 133.5 & 275.2 & 25.1 & 43.3 & 8.4 & 41.7 & 199.5 & 166.1 \\
\hline \multicolumn{13}{|c|}{ Transect 5} \\
\hline 43 & $<\mathrm{dl}$ & $<\mathrm{dl}$ & 2.1 & $<\mathrm{dl}$ & 84.6 & 16.4 & 52.5 & 33.7 & 13.5 & 25.1 & 835.5 & 144.3 \\
\hline 44 & $<\mathrm{dl}$ & $<\mathrm{dl}$ & 6.7 & 20.5 & 456.7 & 70.7 & 32.7 & 138.8 & 10.1 & 177.6 & 465.3 & 59.6 \\
\hline 45 & $<\mathrm{dl}$ & $<\mathrm{dl}$ & $<\mathrm{dl}$ & $<\mathrm{dl}$ & 328.9 & 62.8 & 48.9 & 104.7 & 13.3 & 93.4 & 418.6 & 138.4 \\
\hline 46 & $<\mathrm{dl}$ & 9.7 & $<\mathrm{dl}$ & 60.4 & 600.8 & 74.4 & 29.2 & 138.5 & 7.2 & 84.5 & 316.8 & 86.5 \\
\hline 47 & $<\mathrm{dl}$ & $<\mathrm{dl}$ & $<\mathrm{dl}$ & 12.6 & 86.0 & 22.7 & 9.0 & 50.0 & 3.5 & 70.7 & 162.9 & 59.6 \\
\hline 48 & $<\mathrm{dl}$ & $<\mathrm{dl}$ & $<\mathrm{dl}$ & 9.3 & 169.7 & 103.9 & 18.0 & 36.7 & 5.1 & 33.1 & 69.1 & 138.4 \\
\hline 18 & $<\mathrm{dl}$ & 3.4 & $<\mathrm{dl}$ & $<\mathrm{dl}$ & 87.0 & $<\mathrm{dl}$ & 6.6 & 26.4 & $<$ dl & 25.8 & 30.1 & $<\mathrm{dl}$ \\
\hline \multicolumn{13}{|c|}{ Transect 6} \\
\hline 49 & $<\mathrm{dl}$ & $<\mathrm{dl}$ & $<\mathrm{dl}$ & $<\mathrm{d} l$ & 193.3 & 63.1 & $<\mathrm{dl}$ & $<\mathrm{dl}$ & $<\mathrm{dl}$ & $<\mathrm{dl}$ & 24.5 & $<\mathrm{dl}$ \\
\hline 50 & $<\mathrm{dl}$ & $<\mathrm{dl}$ & $<\mathrm{dl}$ & $<\mathrm{dl}$ & 241.4 & 76.0 & 23.0 & 51.3 & 8.7 & 77.5 & 135.9 & 120.6 \\
\hline 51 & $<\mathrm{dl}$ & $<\mathrm{dl}$ & 4.1 & 5.4 & 237.7 & 61.9 & 20.4 & 27.2 & 5.6 & 24.7 & 172.5 & 74.6 \\
\hline 19 & $<\mathrm{dl}$ & $<\mathrm{dl}$ & $<\mathrm{dl}$ & $<\mathrm{dl}$ & 568.4 & 166.9 & 30.2 & 67.2 & 5.9 & 90.7 & 288.7 & 77.5 \\
\hline
\end{tabular}

$<\mathrm{dl}$, less than the detection limit.

statistical analyses have been done at levels of $P<0.05$ and $P<0.01$.

\section{RATIONALE}

Heavy metals in sediments can be bound in different forms, as is well known, and the main problem is to determine the "winning" competitor in the ligand competition in a narrow range for $\mathrm{pH}$ but wide for redox potential. The main ligands are, of course, $\mathrm{Mn}$ and $\mathrm{Fe}$ oxides (as $\mathrm{Mn} \cdot \mathrm{MnO}_{2}$ ), reactive $\mathrm{Fe}$ or $\mathrm{Fe} \cdot \mathrm{MnO}_{2}$, amorphous $\mathrm{Fe}$ oxides or $\mathrm{Fe} \cdot \mathrm{Fe}_{2} \mathrm{O}_{3}$ (Horowitz et al., 1989), clay, sulfides and organic matter (as humic acids). In a sulfide-poor environment, the adsorption could be interpreted in terms of competition between metals and protons for surface sites. The negative log surface constants of the heavy metals ( $\mathrm{p}^{*} \beta 1$ [surf]) can range from the lowest one of 1.7 for $\mathrm{Pb}$ to the highest one of 3.8 for $\mathrm{Ni}$, with $\mathrm{Zn}$, $\mathrm{Cd}$ and $\mathrm{Cu}$ showing values of $3.6,3.7$ and 1.8, respectively. The role of manganese is different, depending on the $\mathrm{pH}$ and redox conditions. One reaction is the formation of $\mathrm{Mn}(\mathrm{OH})_{4}$ which, with a $\mathrm{p} K_{\text {so }}$ of 56 , can coprecipitate many other metals (Takamatsu et al., 1985).

Not only does Mn (similar to Fe) acts as adsorber during the oxide/hydroxide co-precipitation, but the metal itself could react with $\mathrm{Fe}$ or itself to form stable and solid compounds. A typical example is with $\mathrm{Zn}$, which could be adsorbed on $\mathrm{Mn} / \mathrm{Fe}$-oxi-hydroxides or precipitate forming a franklinite-type double oxide after $\mathrm{Zn}^{2+}+2 \mathrm{Fe}^{3+}+4 \mathrm{H}_{2} \mathrm{O} \Rightarrow \mathrm{ZnFe}_{2} \mathrm{O}_{4}+8 \mathrm{H}^{+}$(Pulford and Bakhsh, 1989). However, the adsorption process can approach a true equilibrium only in very old sediment where, on the other hand, the diagenesis modified completely the dissolution and the release kinetics. In an acceptable time range (days), as in an estuary or where sediments have rapid turnover rates, one can assume that the considered hydrous oxides can behave as a metastable phase. If this were true, it would be possible to estimate a $K_{d}$ value of about one order of magnitude with respect to $\mathrm{Fe}$ oxide $\left(\mathrm{Fe}^{3+}\right.$ ) for $\mathrm{Mn}$ oxides (as $\mathrm{MnO}_{2}$ ) and more than two order of magnitude for clay (bentonite) at $\mathrm{pH} 8$ (Oakley et al., 1981), highlighting the importance of 
Table 2. Guanabara Bay sediments-descriptive statistical analysis of the metal distribution in different GPHs (all values in $\mathrm{mg} / \mathrm{kg} \mathrm{d.w.)}$

\begin{tabular}{|c|c|c|c|c|c|c|}
\hline Metal & Phase & Min & Max & Median & Mean & $\begin{array}{c}\text { Coefficient } \\
\text { of variation }\end{array}$ \\
\hline $\mathrm{Cr}$ & 4th & 0.0 & 186.5 & 18.7 & 24.5 & 127.8 \\
\hline $\mathrm{Cr}$ & 5th & 0.0 & 10.4 & 0.0 & 1.4 & 190.3 \\
\hline $\mathrm{Cr}$ & $\mathrm{HNO}_{3}$ & 1.9 & 279.2 & 41.7 & 59.7 & 91.6 \\
\hline $\mathrm{Cr}$ & HF & 0.2 & 322.0 & 68.4 & 81.5 & 81.0 \\
\hline $\mathrm{Cu}$ & 4th & 0.0 & 138.8 & 18.4 & 28.4 & 113.3 \\
\hline $\mathrm{Cu}$ & 5 th & 0.0 & 20.3 & 0.0 & 1.9 & 200.7 \\
\hline $\mathrm{Cu}$ & $\mathrm{HNO}_{3}$ & 0.0 & 478.0 & 52.0 & 87.8 & 119.7 \\
\hline $\mathrm{Cu}$ & $\mathrm{HF}$ & 0.0 & 242.0 & 60.8 & 79.5 & 76.8 \\
\hline $\mathrm{Ni}$ & 4th & 0.0 & 16.7 & 7.0 & 6.5 & 69.1 \\
\hline $\mathrm{Ni}$ & $\mathrm{HNO}_{3}$ & 5.0 & 60.8 & 24.1 & 24.5 & 35.8 \\
\hline $\mathrm{Ni}$ & $\mathrm{HF}$ & 6.4 & 80.4 & 35.2 & 34.2 & 37.5 \\
\hline $\mathrm{F} b$ & 4th & 0.0 & 139.3 & 23.3 & 27.6 & 99.2 \\
\hline $\mathrm{F} b$ & 5 th & 0.0 & 56.8 & 0.0 & 4.4 & 229.9 \\
\hline $\mathrm{Fb}$ & $\mathrm{HNO}_{3}$ & 4.7 & 460.0 & 72.8 & 120.0 & 98.4 \\
\hline $\mathrm{F} b$ & $\mathrm{HF}$ & 18.2 & 556.0 & 100.5 & 122.9 & 79.7 \\
\hline $2 / n$ & $1 \mathrm{st}$ & 0.0 & 10.3 & 1.1 & 1.8 & 134.8 \\
\hline Zn & 2nd & 0.0 & 157.5 & 34.3 & 47.0 & 90.7 \\
\hline Zn & $3 r d$ & 0.0 & 452.3 & 67.8 & 85.8 & 106.7 \\
\hline Żn & 4th & 0.0 & 256.7 & 74.5 & 85.5 & 75.3 \\
\hline Zn & 5th & 0.0 & 260.9 & 22.0 & 65.5 & 117.8 \\
\hline $2, n$ & $\mathrm{HNO}_{3}$ & 10.4 & 1660 & 242.0 & 384.0 & 93.6 \\
\hline Żn & $\mathrm{HF}$ & 8.6 & 940.0 & 0.0 & 237.5 & 84.3 \\
\hline$M n$ & 1st & 0.0 & 95.7 & 5.6 & 13.9 & 141.0 \\
\hline$M n$ & 2nd & 0.0 & 354.3 & 42.7 & 66.5 & 112.0 \\
\hline $\mathrm{Mn}$ & 3rd & 0.0 & 719.8 & 72.2 & 110.2 & 115.8 \\
\hline Mn & 4th & 0.0 & 585.7 & 118.8 & 158.0 & 89.0 \\
\hline $\mathrm{Mn}$ & 5 th & 0.0 & 43.4 & 13.3 & 12.4 & 85.5 \\
\hline Mn & $\mathrm{HNO}_{3}$ & 13.2 & 1600 & 437.0 & 512.3 & 67.9 \\
\hline Mn & HF & 25.6 & 1410 & 438.8 & 466.8 & 64.9 \\
\hline $\mathrm{Fe}$ & $1 \mathrm{st}$ & 0.0 & 72.1 & 0.0 & 5.2 & 260.9 \\
\hline $\mathrm{Fe}$ & 2nd & 0.0 & 2724 & 21.1 & 148.0 & 290.2 \\
\hline $\mathrm{Fe}$ & $3 \mathrm{rd}$ & 0.0 & 8417 & 2240 & 2510 & 88.2 \\
\hline $\mathrm{Fe}$ & 4 th & 0.0 & 20,880 & 5588 & 6186 & 78.2 \\
\hline $\mathrm{Fe}$ & Sth & 0.0 & 9585 & 3328 & 3270 & 58.6 \\
\hline $\mathrm{Fe}$ & $\mathrm{HNO}_{3}$ & 1160 & 83,800 & 36,550 & 42,210 & 49.6 \\
\hline $\mathrm{Fe}$ & $\mathbf{H F}$ & 1272 & 109,000 & 54,020 & 51,100 & 54.7 \\
\hline \multicolumn{2}{|c|}{ Volatile solids } & 0.7 & 26.0 & 17.0 & 15.2 & 37.6 \\
\hline
\end{tabular}

Mn oxide as the main factor in oxidic sediment metal absorption.

The role played by clays, compared with that of the $\mathrm{Mn}$ and Fe oxihydroxides, seems to be less important but worth considering (Tuin and Tels, 1990). In salt-water sediments the values of $K_{\mathrm{d}}$ range between 43.0 for the $\mathrm{Cu}$ to 1.1 for $\mathrm{Cd}$, low values if compared with the $K_{d}$ value of $\mathrm{MnO}_{2}$ (7339 and 15, respectively).

In reduced sediment, the presence of hydrogen sulfide complicates the metal sinking processes because it allows the formation of a series of equilibria like $\mathrm{Me}(\mathrm{OH})_{2 a d s} \Leftrightarrow \mathrm{Me}(\mathrm{OH})_{2 \text { tree }} \Leftrightarrow$ $\mathrm{Me}^{++}+2 \mathrm{OH}^{-}$and $\mathrm{Me}^{++}+\mathrm{HS}^{-} \Leftrightarrow \mathrm{Me}(\mathrm{HS})^{+}$and $\mathrm{Me}^{++}+\mathrm{nS}^{-} \Leftrightarrow \mathrm{Me}\left(\mathrm{S}_{n}^{(n-2)-}\right.$, where the first term represents the metal hydroxide adsorbed on the $\mathrm{Mn}$ hydroxide. Considering the solubility products $\left(K_{\mathrm{so}}\right)$ as indicators of the stability constants of the metal-ligand complexes (which could be the $\mathrm{OH}^{-}$ion or the $\mathrm{S}^{--}$, or $\mathrm{HS}^{-}$ions), it seems that only some hydroxides could compete with the binding capability of sulfide ions shifting the equilibria of the other metals towards the formation of $\mathrm{Me}(\mathrm{S})_{n}^{(n-2)-}$ complex/precipitates. At the bay water $\mathrm{pH}(6-8)$ the $\mathrm{p} K_{\mathrm{a}}$ of the system $\mathrm{H}_{2} \mathrm{~S} / \mathrm{S}=$ is 22 . With a sulfide saturation value of $0.1 \mathrm{~mol} / \mathrm{liter}$, the $\mathrm{p} S$ values of the involved metals results (at $\mathrm{pH}=8$ ) in not more than 18.5 for $\mathrm{Cd}, 28.5$ for $\mathrm{Cu}$, between 14 and 20 for $\mathrm{Ni}$, between 14.0 and 17.0 for $\mathrm{Zn}$ and 14.0 for $\mathrm{Pb}$. Competition will exist among $\mathrm{Mn}$ and $\mathrm{Fe}$ hydroxides and sulfides,

Table 3. Tentative risk level classification for marine sediment calculated from Jonkers and Everts (1992), Ontario Ministry for Environment (1988) and Webster and Ridgway (1994) according to metal concentrations extracted by hot concentrated nitric acid procedure (values in ppm)

\begin{tabular}{lcccc}
\hline & No-risk level & 1st risk level & 2nd risk level & Maximum risk level \\
\hline $\mathrm{Cd}$ & $<0.5$ & $0.5-5.0$ & $5.0-50$ & $>50$ \\
$\mathrm{Cr}$ & $<25$ & $25-50$ & $50-120$ & $>120$ \\
$\mathrm{Cu}$ & $<0.7$ & $0.7-7.0$ & $7.0-70$ & $>70$ \\
$\mathrm{Fe}$ & $<10$ & $10-100$ & $100-350$ & $>350$ \\
$\mathrm{Ni}$ & $<25$ & $25-30$ & $30-60$ & $>60$ \\
$\mathrm{~Pb}$ & $<12$ & $12-120$ & $120-1200$ & $>1200$ \\
$\mathrm{Zn}$ & $<3.5$ & $3.5-35$ & $35-350$ & $>350$ \\
\hline
\end{tabular}




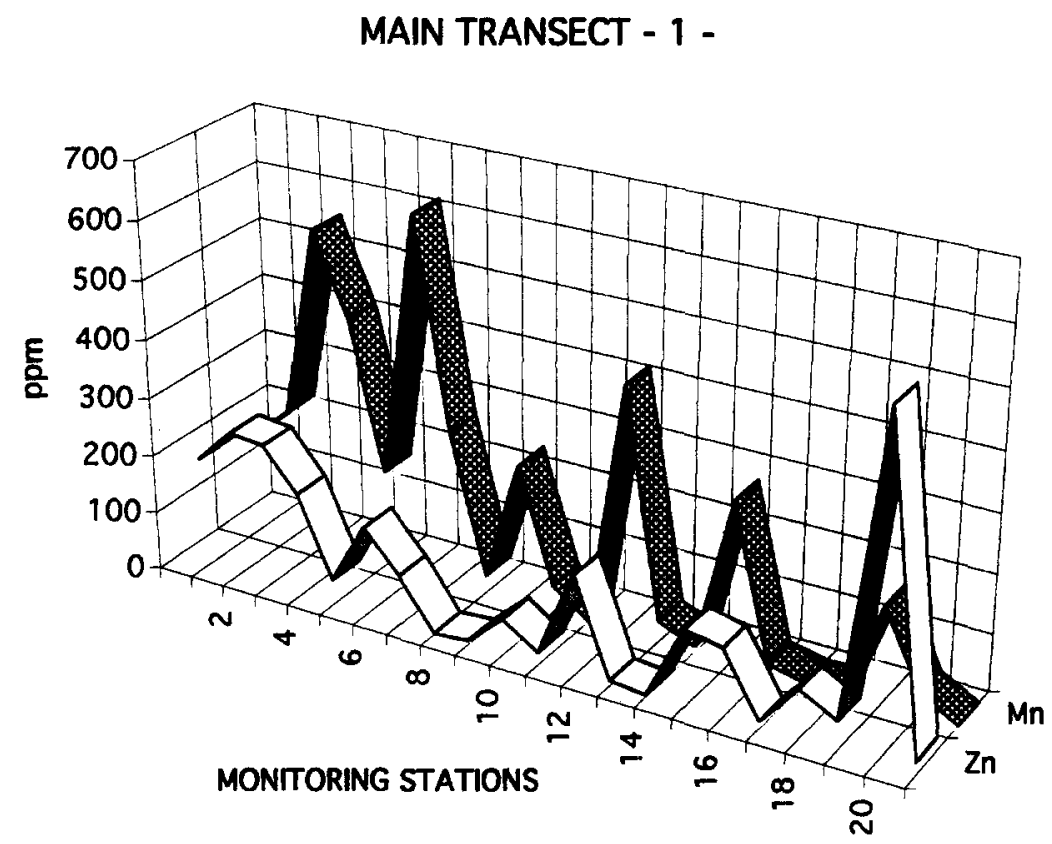

Fig. 2. Main transect-sum of the GPHs 1, 2 and 3 of zinc and manganese (BAP)

with exclusion of $\mathrm{Mn}(\mathrm{OH})_{4}\left(\mathrm{p} K_{\mathrm{so}}\right.$ for the hydroxide $=56)$ being the $\mathrm{p} K_{\mathrm{so}}$ of $\mathrm{Mn}(\mathrm{OH})_{2}$ and $\mathrm{Fe}(\mathrm{OH})_{2}$, 12.5 and 15.0 , respectively. The corresponding sulfides have the $\mathrm{p} K_{\mathrm{so}}$ between 12.0 and 17.0 (Butler, 1964; Fernex et al., 1989).

Organic matter, as humic acid, has low stability constants for metals, ranging from about 3.7 to 4.0 at $\mathrm{pH} 5$ and $m=0.1$. Because the $\mathrm{p} K$ is increasing with $\mathrm{pH}$ and decreasing with $m$, it seems reasonable to think that humic acids play a limited role as complexing compounds in very saline sediments compared with that exerted by the $\mathrm{Mn} / \mathrm{Fe}$-oxides and the sulfides (Schnitzer and Khan, 1972).

\section{CONCLUSION}

The graphics of Figs 2, 3, 4 and 5 and the data in Table 1 show, for the main transect, high levels of $\mathrm{Zn}$ and Mn pollution in the inner part of the bay either in the BAP or in the NBAP forms. Cr shows a well-defined decreasing behavior from the internal part to the open ocean, but its species are mostly non-bioavailable. $\mathrm{Cu}, \mathrm{Ni}$ and $\mathrm{Pb}$ show some peaks in specific points, with the maxima in the area close to the gateway below the Rio-Niteroi bridge and between Botafogo and Flamengo beaches and the Niteroi bay. Transect 2 indicates high levels of $\mathrm{Zn}$ and $\mathrm{Mn}$, either BAP or NBAP; $\mathrm{Cr}, \mathrm{Cu}, \mathrm{Ni}$ and $\mathrm{Pb}$ are present only as NBAP in relatively high concen-

MAIN TRANSECT -1-

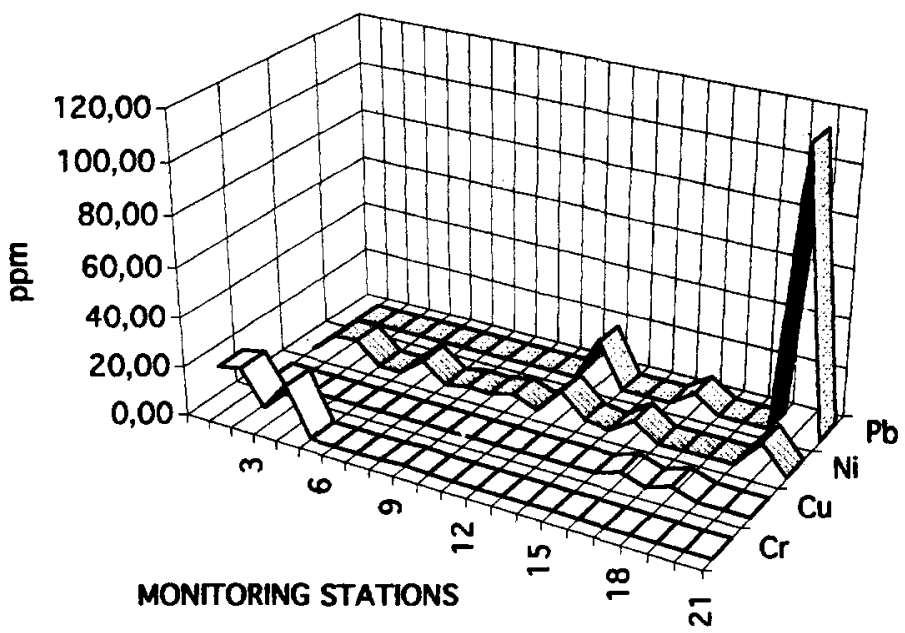

Fig. 3. Main transect-sum of the GPHs 1, 2 and 3 for chromium, copper, nickel and lead (BAP). 


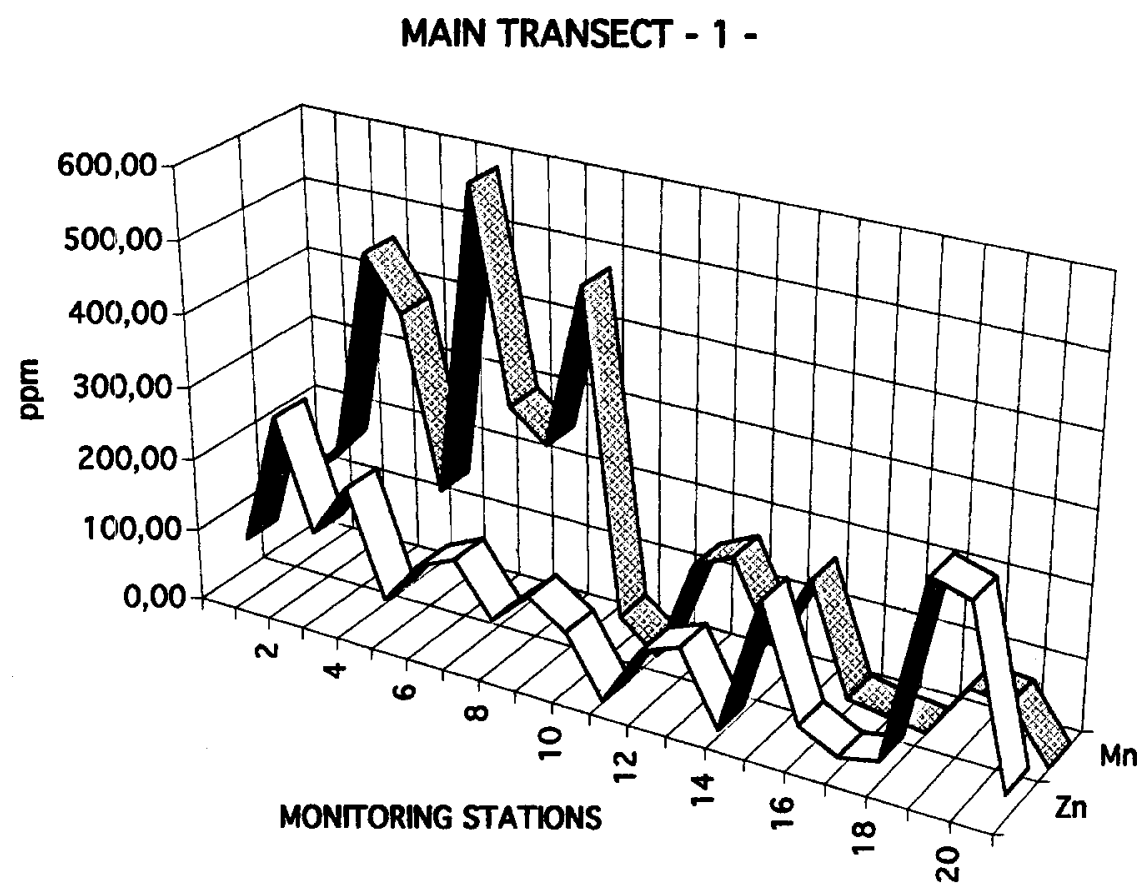

Fig. 4. Main transect-sum of the GPHs 4 and 5 of zinc and manganese (NBAP).

trations (especially $\mathrm{Cu}$ ). Transect 3 shows $\mathrm{Mn}$ and $\mathrm{Ni}$ as the most important metals in the BAPs, while $\mathrm{Pb}$ is the most significant in the NBAP. Transect 4 (crossing the bay from west to east above the bridge) shows a clearly decreasing BAP and NBAP $\mathrm{Cr}$ along the transect; BAP and NBAP concentrations are, surprisingly, very alike. Quite high concentrations of BAP $\mathrm{Zn}$ and $\mathrm{Mn}$ (both forms) are, also, present in the transect. Transect 5 shows the strong influence on the sediment quality of the downtown area and of the
Canal do Cunha and Canal do Mangue. Both are like sewers collecting sewage and industrial wastes of a large part of Rio de Janeiro. Their effects are clearly evident from the sediment metal pollution data. BAP $\mathrm{Pb}, \mathrm{BAP}$ and NBAP $\mathrm{Zn}$ and NBAP $\mathrm{Cu}$ indicate strong pollution sources which influence the bay also off-shore. Finally, Transect 6 reveals the role of an industrial area (Niteroi), discharging its effluents in the inner Niteroi bay flowing in the Guanabara; apparently, the Niteroi bay is not very polluted, with

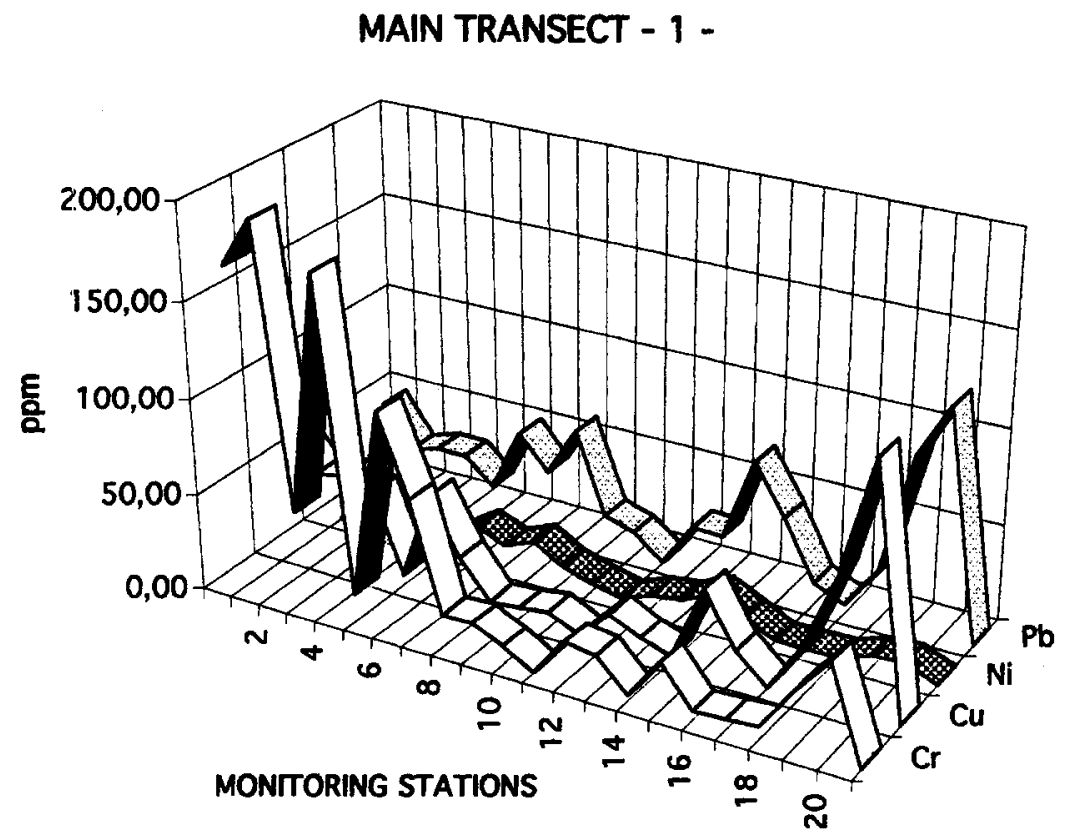

Fig. 5. Main transect-sum of the GPHs 4 and 5 of chromium, copper, nickel and lead (NBAP). 
Table 4. Distribution in different classes of risk levels of the metals in the sediments of Guanabara Bay (referring to the hot $\mathrm{HNO}_{3}$-extracted metals (anthropogenic phase) and expressed as percentage of the monitoring stations)

\begin{tabular}{lcccc}
\hline & No-risk level & 1st risk level & 2nd risk level & Maximum risk level \\
\hline $\mathrm{Cd}$ & 6 & 73 & 21 & 0 \\
$\mathrm{Cr}$ & 18 & 48 & 23 & 11 \\
$\mathrm{Cu}$ & 0 & 3 & 55 & 42 \\
$\mathrm{Fe}$ & 12 & 88 & 0 & 0 \\
$\mathrm{Ni}$ & 56 & 31 & 11 & 2 \\
$\mathrm{~Pb}$ & 7 & 60 & 33 & 0 \\
$\mathrm{Zn}$ & 0 & 5 & 61 & 34 \\
\hline
\end{tabular}

only BAP $\mathrm{Zn}$ and $\mathrm{NBAP} \mathrm{Pb}$ at relatively high concentrations.

The descriptive analysis (Table 2) shows a high prevalence of GPH4, in the sense that most of $\mathrm{Cr}, \mathrm{Cu}, \mathrm{Ni}$ and $\mathrm{Pb}$ seem to be mostly extractable in this phase, emphasizing the role played by sulfide and organic matter as main adsorber/ ligands. GPH3, indeed, accounts for a minimum of $60 \%$ to a maximum of $100 \%$ of the total extractable metal for $\mathrm{Cr}, \mathrm{Cu}, \mathrm{Ni}$ and $\mathrm{Pb}$. The very high sulfide/organic matter complexing values for the $\mathrm{Cr}$, which is not forming sulfide, could be explained by the co-precipitation/adsorption of the $\mathrm{Cr}$ oxides with and on $\mathrm{Fe}$ and $\mathrm{Mn}$ sulfide. $\mathrm{Zn}$, as expected, seems to be distributed homogeneously in all the GPHs except the first. A relatively balanced distribution, according to their role as adsorber, is shown by $\mathrm{Fe}$ and $\mathrm{Mn}$, especially in the fourth, second and third $(\mathrm{Mn})$ geochemical speciation and in the fourth, third and fifth GPH for Fe. Furthermore, the high values of the GPH5 of $\mathrm{Fe}$ validated the fifth extraction step in the sequential extraction analysis as proposed by Chen et al. (1976).

Analyzing the whole bay as global system, referring to Table 3, and, therefore, considering only the so-called anthropogenic phase extracted by hot nitric acid, it can be seen that the $\mathrm{Cu}$ and $\mathrm{Zn}$ are the main pollutants, the first one exceeding the MRL in the $42 \%$ of the stations and with a $55 \%$ of the values in the second risk level (the second one goes beyond the MRL in the $34 \%$ and attains the second risk level in the $62 \%$ of the samples).

The correlation matrices (Tables 5, 6, 7 and 8) gave a very low relation among the five metals (as already discussed, Cd was not considered because of its extremely low concentration in all the phases) and the different species of $\mathrm{Fe}$ and $\mathrm{Mn}$ present in the

Table 5. GPH 3-correlation matrix among the phase-extracted metals, VS and the different species of Fe and $\mathrm{Mn}(N=54$, casewise deletion of missing data)

\begin{tabular}{|c|c|c|c|c|c|c|c|c|c|c|c|c|c|c|c|c|}
\hline $\begin{array}{l}\mathrm{Cr} \\
\text { 3rd } \\
\text { GPH } \\
\text { A }\end{array}$ & $\begin{array}{c}\mathrm{Cu} \\
\text { 3rd } \\
\text { GPH } \\
\text { B }\end{array}$ & $\begin{array}{c}\mathrm{Ni} \\
\text { 3rd } \\
\text { GPH } \\
\mathrm{C}\end{array}$ & $\begin{array}{c}\mathrm{Pb} \\
\text { 3rd } \\
\mathrm{GPH} \\
\mathrm{D}\end{array}$ & $\begin{array}{c}\mathrm{Zn} \\
3 \mathrm{rd} \\
\mathrm{GPH} \\
\mathrm{E}\end{array}$ & $\begin{array}{c}\mathrm{Fe} \\
\mathrm{b} \\
\mathrm{F}\end{array}$ & $\begin{array}{c}\mathrm{Mn} \\
\mathrm{b} \\
\mathrm{G}\end{array}$ & $\begin{array}{c}\text { VS } \\
\mathrm{H}\end{array}$ & $\begin{array}{c}\mathrm{Fe} \\
2 \mathrm{nd} \\
\text { GPH } \\
\text { I }\end{array}$ & $\begin{array}{c}\mathrm{Fe} \\
3 \mathrm{rd} \\
\mathrm{GPH} \\
\mathrm{J}\end{array}$ & $\begin{array}{c}\text { Fe } \\
4 \text { th } \\
\text { GPH } \\
\text { K }\end{array}$ & $\begin{array}{c}\text { Fe } \\
\text { Sth } \\
\text { GPH } \\
\text { L }\end{array}$ & $\begin{array}{c}\text { Mn } \\
\text { 2nd } \\
\text { GPH } \\
\text { M }\end{array}$ & $\begin{array}{c}\text { Mn } \\
\text { 3rd } \\
\text { GPH } \\
\mathbf{N}\end{array}$ & $\begin{array}{c}\text { Mn } \\
4 \text { th } \\
\text { GPH } \\
O\end{array}$ & $\begin{array}{c}\text { Mn } \\
\text { 5th } \\
\text { GPH } \\
\text { P }\end{array}$ & \\
\hline \multirow[t]{14}{*}{1.00} & $\begin{array}{l}0.94 \\
* * *\end{array}$ & $\begin{array}{l}0.92 \\
* * * *\end{array}$ & $\begin{array}{l}0.60 \\
* * *\end{array}$ & 0.04 & -0.13 & -0.08 & $\begin{array}{l}0.87 \\
* * * *\end{array}$ & 0.01 & 0.00 & -0.10 & -0.13 & 0.19 & 0.10 & 0.06 & 0.27 & A \\
\hline & 1.00 & $\begin{array}{l}0.95 \\
* * *\end{array}$ & $\begin{array}{l}0.68 \\
* * *\end{array}$ & 0.07 & -0.24 & -0.16 & $\begin{array}{l}0.89 \\
* * * *\end{array}$ & 0.06 & -0.13 & -0.16 & -0.21 & 0.11 & 0.02 & -0.04 & $\stackrel{0.31}{*}$ & B \\
\hline & & 1.00 & $\begin{array}{l}0.70 \\
* * *\end{array}$ & 0.10 & -0.15 & -0.13 & $\begin{array}{l}0.89 \\
* * *\end{array}$ & 0.01 & 0.03 & -0.08 & -0.15 & 0.18 & 0.14 & -0.01 & 0.27 & $\mathrm{C}$ \\
\hline & & & 1.00 & $\begin{array}{l}0.60 \\
* * *\end{array}$ & -0.23 & -0.21 & $\begin{array}{l}0.62 \\
* * * *\end{array}$ & $\begin{array}{l}0.47 \\
* * *\end{array}$ & 0.04 & -0.01 & -0.15 & 0.02 & -0.11 & -0.14 & 0.12 & D \\
\hline & & & & 1.00 & 0.13 & -0.07 & 0.16 & $\begin{array}{l}0.70 \\
* * *\end{array}$ & $\stackrel{0.38}{*}$ & $\begin{array}{c}0.43 \\
*\end{array}$ & 0.05 & 0.09 & -0.05 & 0.01 & -0.23 & $E$ \\
\hline & & & & & 1.00 & $\begin{array}{l}0.55 \\
* * *\end{array}$ & 0.06 & -0.10 & $\begin{array}{c}0.66 \\
* * *\end{array}$ & $\begin{array}{l}0.59 \\
* * *\end{array}$ & $\begin{array}{l}0.55 \\
* * *\end{array}$ & $\begin{array}{c}0.41 \\
*\end{array}$ & $\begin{array}{l}0.60 \\
* * *\end{array}$ & $\begin{array}{l}0.59 \\
* * *\end{array}$ & -0.12 & $\mathrm{~F}$ \\
\hline & & & & & & 1.00 & 0.12 & -0.07 & $\begin{array}{c}0.27 \\
*\end{array}$ & $\begin{array}{c}0.35 \\
*\end{array}$ & $\begin{array}{l}0.44 \\
* * *\end{array}$ & $\begin{array}{l}0.60 \\
* * *\end{array}$ & $\begin{array}{l}0.69 \\
* * *\end{array}$ & $\begin{array}{l}0.83 \\
* * *\end{array}$ & 0.20 & G \\
\hline & & & & & & & 1.00 & 0.11 & 0.10 & 0.07 & 0.06 & $\begin{array}{c}0.32 \\
*\end{array}$ & 0.24 & 0.21 & $\begin{array}{c}0.39 \\
*\end{array}$ & $\mathbf{H}$ \\
\hline & & & & & & & & 1.00 & $\begin{array}{l}0.17 \\
1.00\end{array}$ & $\begin{array}{l}0.09 \\
0.57 \\
* * *\end{array}$ & $\begin{array}{c}0.05 \\
0.41 \\
*\end{array}$ & $\begin{array}{c}0.02 \\
0.43 \\
*\end{array}$ & $\begin{array}{r}-0.15 \\
0.62 \\
* * *\end{array}$ & $\begin{array}{r}-0.12 \\
0.33 \\
*\end{array}$ & $\begin{array}{l}-0.11 \\
-0.26\end{array}$ & I \\
\hline & & & & & & & & & & 1.00 & $\underset{*}{0.32}$ & $\begin{array}{l}0.48 \\
* * *\end{array}$ & $\begin{array}{l}0.48 \\
* * *\end{array}$ & $\begin{array}{l}0.58 \\
* * *\end{array}$ & -0.26 & $\mathrm{~K}$ \\
\hline & & & & & & & & & & & 1.00 & $\begin{array}{l}0.44 \\
* * *\end{array}$ & $\begin{array}{l}0.45 \\
* * *\end{array}$ & $\begin{array}{l}0.47 \\
* * *\end{array}$ & 0.11 & L \\
\hline & & & & & & & & & & & & 1.00 & $\begin{array}{l}0.72 \\
* * *\end{array}$ & $\begin{array}{l}0.67 \\
* * *\end{array}$ & -0.02 & $\mathbf{M}$ \\
\hline & & & & & & & & & & & & & 1.00 & $\begin{array}{l}0.69 \\
* * *\end{array}$ & -0.03 & $\mathbf{N}$ \\
\hline & & & & & & & & & & & & & & 1.00 & $\begin{array}{l}0.04 \\
1.00\end{array}$ & $\begin{array}{l}\mathbf{O} \\
\mathrm{P}\end{array}$ \\
\hline
\end{tabular}


Table 6. GPH 4 -correlation matrix among the phase-extracted metals, VS and the different species of Fe and $\mathrm{Mn}(N=59$, casewise deletion of

\begin{tabular}{|c|c|c|c|c|c|c|c|c|c|c|c|c|c|c|c|c|}
\hline $\begin{array}{l}\mathrm{Cr} \\
\text { 4th } \\
\text { GPH } \\
\text { A }\end{array}$ & $\begin{array}{c}\mathrm{Cu} \\
\text { 4th } \\
\text { GPH } \\
\text { B }\end{array}$ & $\begin{array}{c}\mathrm{Ni} \\
\text { 4th } \\
\text { GPH } \\
\mathrm{C}\end{array}$ & $\begin{array}{c}\mathrm{Pl} b \\
\text { 4th } \\
\text { GFH } \\
\text { C }\end{array}$ & $\begin{array}{c}\mathrm{Zn} \\
\text { 4th } \\
\text { GPH } \\
\text { E }\end{array}$ & $\begin{array}{l}\mathrm{Fe} \\
\mathrm{b} \\
\mathrm{F}\end{array}$ & $\begin{array}{c}\text { Mn } \\
\text { b } \\
\text { G }\end{array}$ & $\begin{array}{l}\text { VS } \\
\text { H }\end{array}$ & $\begin{array}{c}\mathrm{Fe} \\
\text { 2nd } \\
\mathrm{GPH} \\
\mathrm{I}\end{array}$ & $\begin{array}{c}\mathrm{Fe} \\
\text { 3rd } \\
\mathrm{GPH} \\
\mathrm{J}\end{array}$ & $\begin{array}{c}\text { Fe } \\
\text { 4th } \\
\text { GPH } \\
\text { K }\end{array}$ & $\begin{array}{c}\text { Fe } \\
\text { 5th } \\
\text { GPH } \\
\text { L }\end{array}$ & $\begin{array}{c}\text { Mn } \\
\text { 2nd } \\
\text { GPH } \\
\text { M }\end{array}$ & $\begin{array}{c}\text { Mn } \\
\text { 3rd } \\
\text { GPH } \\
\mathbf{N}\end{array}$ & $\begin{array}{c}\text { Mn } \\
\text { 4th } \\
\text { GPH } \\
O\end{array}$ & $\begin{array}{c}\text { Mn } \\
\text { 5th } \\
\text { GPH } \\
\text { P }\end{array}$ & \\
\hline \multirow[t]{14}{*}{1.00} & $\begin{array}{c}0.41 \\
*\end{array}$ & $\begin{array}{c}0.29 \\
*\end{array}$ & 0.35 & $\begin{array}{c}0.49 \\
* * *\end{array}$ & $\begin{array}{c}0.27 \\
*\end{array}$ & 0.23 & $\begin{array}{c}0.37 \\
*\end{array}$ & 0.20 & 0.39 & $\begin{array}{c}0.28 \\
*\end{array}$ & 0.28 & 0.22 & 0.18 & $\begin{array}{c}0.27 \\
*\end{array}$ & 0.00 & A \\
\hline & 1.00 & $\begin{array}{c}0.36 \\
*\end{array}$ & 0.91 & $\begin{array}{l}0.74 \\
* * *\end{array}$ & 0.07 & -0.17 & $\underset{*}{0.38}$ & $\begin{array}{l}0.67 \\
* * *\end{array}$ & 0.23 & $\begin{array}{c}0.40 \\
*\end{array}$ & 0.03 & 0.08 & -0.11 & -0.02 & -0.10 & B \\
\hline & & 1.00 & $\underset{* * *}{0.44}$ & 0.19 & -0.12 & -0.01 & $\begin{array}{l}0.92 \\
* * *\end{array}$ & 0.00 & -0.10 & 0.06 & -0.05 & 0.24 & -0.12 & 0.18 & 0.31 & C \\
\hline & & & 1.00 & $\begin{array}{l}0.69 \\
* * *\end{array}$ & 0.06 & -0.13 & $\underset{*}{0.41}$ & $\begin{array}{l}0.46 \\
* * *\end{array}$ & 0.16 & $\begin{array}{c}0.40 \\
*\end{array}$ & -0.02 & 0.14 & -0.04 & 0.08 & -0.10 & D \\
\hline & & & & 1.00 & 0.23 & -0.07 & 0.25 & $\begin{array}{l}0.63 \\
* * *\end{array}$ & 0.28 & 0.48 & 0.24 & 0.20 & 0.03 & 0.23 & -0.13 & E \\
\hline & & & & & 1.00 & $\begin{array}{l}0.57 \\
* * *\end{array}$ & 0.03 & -0.07 & $\begin{array}{l}0.48 \\
* * *\end{array}$ & 0.42 & 0.40 & 0.06 & 0.10 & 0.25 & -0.09 & $\mathbf{F}$ \\
\hline & & & & & & 1.00 & 0.08 & -0.19 & 0.21 & 0.25 & $\begin{array}{c}0.36 \\
*\end{array}$ & $\underset{*}{0.32}$ & $\begin{array}{c}0.32 \\
*\end{array}$ & $\begin{array}{l}0.56 \\
* * *\end{array}$ & 0.18 & G \\
\hline & & & & & & & 1.00 & 0.11 & 0.10 & 0.09 & 0.07 & $\underset{*}{0.26}$ & 0.19 & 0.21 & $\begin{array}{c}0.39 \\
*\end{array}$ & $\mathrm{H}$ \\
\hline & & & & & & & & 1.00 & $\begin{array}{l}0.14 \\
1.00\end{array}$ & $\begin{array}{l}0.07 \\
0.57 \\
* * *\end{array}$ & $\begin{array}{l}0.04 \\
0.42 \\
* * *\end{array}$ & $\begin{array}{c}0.04 \\
0.38 \\
*\end{array}$ & $\begin{array}{r}-0.14 \\
0.58 \\
* * * *\end{array}$ & $\begin{array}{c}-0.11 \\
0.36 \\
*\end{array}$ & $\begin{array}{l}-0.11 \\
-0.25\end{array}$ & I \\
\hline & & & & & & & & & & 1.00 & $\begin{array}{l}0.35 \\
* * *\end{array}$ & 0.40 & $\begin{array}{l}0.46 \\
* * *\end{array}$ & $\begin{array}{l}0.58 \\
* * * *\end{array}$ & 0.27 & $\mathbf{K}$ \\
\hline & & & & & & & & & & & 1.00 & $\begin{array}{c}0.41 \\
*\end{array}$ & $\begin{array}{l}0.40 \\
* * *\end{array}$ & $\begin{array}{l}0.49 \\
* * *\end{array}$ & 0.10 & $\mathbf{L}$ \\
\hline & & & & & & & & & & & & 1.00 & $\begin{array}{l}0.58 \\
* * *\end{array}$ & $\begin{array}{l}0.71 \\
* * *\end{array}$ & -0.02 & $\mathbf{M}$ \\
\hline & & & & & & & & & & & & & 1.00 & $\begin{array}{l}0.66 \\
* * *\end{array}$ & -0.04 & $\mathbf{N}$ \\
\hline & & & & & & & & & & & & & & 1.00 & $\begin{array}{l}0.02 \\
1.00\end{array}$ & $\begin{array}{l}\mathrm{O} \\
\mathrm{P}\end{array}$ \\
\hline
\end{tabular}

${ }^{*} P<0.05 ;{ }^{* * *} P<0.001$.

sediment. Good correlation was found, however, with VS.

The correlation matrices were calculated at $P<0.05$ and $P<0.001$ only for the metals extracted as GPHs 3, 4 and 5. Data of the GPHs 1, and 2 were mostly below the analytical detection limit. Correlation were done among the extracted metal in specific GPH with VS and all the forms of Fe and $\mathrm{Mn}$, including those extracted by dissolution with hydrofluoric plus nitric acid. The results show for the metals extracted in GPH3 (Table 5) good correlation among $\mathrm{Cr}, \mathrm{Cu}, \mathrm{Ni}$ and $\mathrm{Pb}$ and $\mathrm{VS}$, statistically reliable at $P<0.001$ level. $\mathrm{Pb}$ and $\mathrm{Zn}$ correlate, also, to Fe GPH2 the level of $P<0.05$. Metals extracted in GPH4 (Table 6) correlate highly $(P<0.001)$ but with a small coefficient to $\mathrm{Fe}$ GPH2 ( $\mathrm{Cu}, \mathrm{Pb}$ and $\mathrm{Zn})$ and Fe GPH4 (Zn). In GPH5 (Table 7) significant correlation $(P<0.001)$ and high coefficients of correlation to different forms of $\mathrm{Fe}$ and $\mathrm{Mn}$ are shown by $\mathrm{Cr}, \mathrm{Cu}$ and $\mathrm{Ni}$ (small coefficient for $\mathrm{Pb}$ ). Finally, no correlation were found among anthropogenic metal (hot $\mathrm{HNO}_{3}$ extraction) and total $\mathrm{Fe}$ and total $\mathrm{Mn}$ (hydrofluoric plus nitric acid extraction).

\section{FINAL COMMENTS}

The results of the investigation indicate a stressed environment where a low level of oxygen in the bottom causes a strong reduction of the organic sulfur with the production of a high level of hydrogen sulfide. The statistical correlation analysis demonstrated that $\mathrm{Fe}$ and $\mathrm{Mn}$ oxides and hydroxides seem not to be the main responsible factors of the metal sinking in the sediments of Guanabara Bay. Therefore, the conclusion is that hydrogen sulfide and humic acids (organic matter) are the most important devices in regulating the amount of free or bioavailable metals in the sediment and, therefore, in the metal exchange between the biota and the water. As discussed above, the authors think that hydrogen sulfide in such a reductive environment like the bottom sediment of Guanabara Bay must play the major role. Its presence in large amounts will produce very insoluble sulfide with the metal accumulated and adsorbed in the sediment. The large amount of hydrogen sulfide undoubtedly shifts the adsorption equilibria of the $\mathrm{Mn} / \mathrm{Fe} /$ humic acids/clay, forcing a continuous release from that system of heavy metal ions, immediately bonded to the sulfide ion in order to maintain the thermodynamic conditions of the solubility products.

Generally speaking, the bay of Guanabara is highly polluted with toxic metals, and the associated risk seems to be high (according to Table 3) for $\mathrm{Cu}$ and $\mathrm{Zn}$. In a more accurate environmental point of view, however, it shows a relatively low risk with regard to the metals in the sediment. The bioavailability of those metals (BAPs), indeed, as demonstrated through the speciation analysis, seems, now, to be small compared with the total and 
Table 7. GPH 5 - correlation matrix among the phase-extracted metals, VS and the different species of Fe and $\mathrm{Mn}(N=59$, casewise deletion of

\begin{tabular}{|c|c|c|c|c|c|c|c|c|c|c|c|c|c|c|c|c|}
\hline $\begin{array}{l}\mathrm{Cr} \\
\text { 5th } \\
\mathrm{GPH} \\
\mathrm{A} \\
\end{array}$ & $\begin{array}{c}\mathrm{Cu} \\
5 \text { th } \\
\text { GPH } \\
\text { B } \\
\end{array}$ & $\begin{array}{c}\mathrm{Ni} \\
\text { Sth } \\
\text { GPH } \\
\mathrm{C}\end{array}$ & $\begin{array}{c}\mathrm{Pb} \\
5 \mathrm{th} \\
\text { GPH } \\
\mathrm{D}\end{array}$ & $\begin{array}{c}\text { Zn } \\
5 \text { th } \\
\text { GPH } \\
\text { E } \\
\end{array}$ & $\begin{array}{c}\mathrm{Fe} \\
\mathrm{b} \\
\mathrm{F} \\
\end{array}$ & $\begin{array}{c}\mathrm{Mn} \\
\mathrm{b} \\
\mathrm{G} \\
\end{array}$ & $\begin{array}{l}\text { VS } \\
\text { H } \\
\end{array}$ & $\begin{array}{c}\mathrm{Fe} \\
2 \mathrm{nd} \\
\mathrm{GPH} \\
\mathrm{I} \\
\end{array}$ & $\begin{array}{c}\mathrm{Fe} \\
\text { 3rd } \\
\text { GPH } \\
\mathrm{J} \\
\end{array}$ & $\begin{array}{c}\mathrm{Fe} \\
4 \mathrm{th} \\
\mathrm{GPH} \\
\mathrm{K} \\
\end{array}$ & $\begin{array}{c}\mathrm{Fe} \\
5 \mathrm{th} \\
\mathrm{GPH} \\
\mathrm{L} \\
\end{array}$ & $\begin{array}{c}\mathrm{Mn} \\
\text { 2nd } \\
\text { GPH } \\
\text { M } \\
\end{array}$ & $\begin{array}{c}\mathrm{Mn} \\
3 \mathrm{rd} \\
\text { GPH } \\
\mathrm{N} \\
\end{array}$ & $\begin{array}{c}\text { Mn } \\
\text { 4th } \\
\text { GPH } \\
O \\
\end{array}$ & $\begin{array}{c}\text { Mn } \\
\text { 5th } \\
\text { GPH } \\
P \\
\end{array}$ & \\
\hline \multirow[t]{15}{*}{1.00} & $\begin{array}{l}0.95 \\
* * * *\end{array}$ & $\begin{array}{l}0.96 \\
* * * *\end{array}$ & $\begin{array}{l}0.67 \\
* * * *\end{array}$ & 0.10 & -0.11 & -0.02 & $\begin{array}{l}0.89 \\
* * *\end{array}$ & -0.04 & -0.15 & -0.18 & -0.13 & 0.06 & -0.02 & -0.01 & $\begin{array}{l}0.46 \\
* * *\end{array}$ & A \\
\hline & 1.00 & $\begin{array}{l}0.94 \\
* * * *\end{array}$ & $\begin{array}{l}0.70 \\
* * * *\end{array}$ & 0.06 & -0.15 & -0.12 & $\begin{array}{l}0.89 \\
* * *\end{array}$ & 0.07 & -0.12 & -0.20 & -0.15 & 0.09 & -0.04 & -0.07 & $\begin{array}{c}0.32 \\
*\end{array}$ & B \\
\hline & & 1.00 & $\begin{array}{l}0.74 \\
* * *\end{array}$ & 0.03 & -0.22 & -0.11 & $\begin{array}{l}0.88 \\
* * *\end{array}$ & -0.04 & -0.20 & -0.23 & -0.25 & 0.02 & -0.05 & -0.10 & $\begin{array}{l}0.46 \\
* * *\end{array}$ & C \\
\hline & & & 1.00 & 0.11 & $\begin{array}{c}0.27 \\
*\end{array}$ & -0.19 & $\begin{array}{l}0.61 \\
* * *\end{array}$ & $\begin{array}{c}0.20 \\
*\end{array}$ & $\begin{array}{c}0.39 \\
*\end{array}$ & $\begin{array}{c}0.41 \\
*\end{array}$ & -0.23 & -0.14 & -0.25 & $\begin{array}{c}0.29 \\
*\end{array}$ & $\begin{array}{l}0.59 \\
* * *\end{array}$ & D \\
\hline & & & & 1.00 & -0.03 & -0.03 & 0.13 & 0.03 & 0.01 & 0.15 & $\begin{array}{c}0.29 \\
*\end{array}$ & 0.07 & 0.08 & 0.07 & 0.21 & $\mathbf{E}$ \\
\hline & & & & & 1.00 & $\begin{array}{l}0.57 \\
* * *\end{array}$ & 0.03 & -0.07 & $\begin{array}{l}0.48 \\
* * *\end{array}$ & $\begin{array}{l}0.42 \\
* * *\end{array}$ & $\begin{array}{l}0.40 \\
* * *\end{array}$ & 0.06 & $\underset{*}{0.10}$ & 0.25 & -0.09 & $\mathbf{F}$ \\
\hline & & & & & & 1.00 & 0.08 & -0.19 & 0.21 & 0.25 & $\begin{array}{l}0.36 \\
* * *\end{array}$ & $\underset{*}{0.32}$ & $\begin{array}{c}0.32 \\
*\end{array}$ & $\begin{array}{l}0.56 \\
* * *\end{array}$ & 0.18 & G \\
\hline & & & & & & & 1.00 & 0.11 & 0.10 & 0.09 & 0.07 & $\begin{array}{c}0.26 \\
*\end{array}$ & 0.19 & 0.21 & $\underset{*}{0.39}$ & $\mathrm{H}$ \\
\hline & & & & & & & & 1.00 & 0.14 & 0.07 & 0.04 & 0.04 & -0.14 & -0.11 & -0.11 & I \\
\hline & & & & & & & & & 1.00 & $\begin{array}{l}0.57 \\
* * *\end{array}$ & $\begin{array}{c}0.42 \\
*\end{array}$ & $\begin{array}{c}0.38 \\
*\end{array}$ & $\begin{array}{l}0.58 \\
* * *\end{array}$ & $\begin{array}{c}0.36 \\
*\end{array}$ & -0.25 & $\mathbf{J}$ \\
\hline & & & & & & & & & & 1.00 & $\begin{array}{c}0.35 \\
*\end{array}$ & $\begin{array}{c}0.40 \\
*\end{array}$ & $\begin{array}{l}0.46 \\
* * *\end{array}$ & $\begin{array}{l}0.58 \\
* * *\end{array}$ & $\begin{array}{l}0.27 \\
*\end{array}$ & $\mathrm{~K}$ \\
\hline & & & & & & & & & & & 1.00 & $\begin{array}{c}0.41 \\
*\end{array}$ & $\begin{array}{c}0.40 \\
*\end{array}$ & $\begin{array}{l}0.49 \\
* * *\end{array}$ & 0.10 & L \\
\hline & & & & & & & & & & & & 1.00 & $\begin{array}{c}0.58 \\
*\end{array}$ & $\begin{array}{l}0.71 \\
* * *\end{array}$ & -0.02 & M \\
\hline & & & & & & & & & & & & & 1.00 & $\begin{array}{l}0.66 \\
* * *\end{array}$ & -0.04 & $\mathbf{N}$ \\
\hline & & & & & & & & & & & & & & 1.00 & $\begin{array}{l}0.02 \\
1.00\end{array}$ & $\begin{array}{l}\mathrm{O} \\
\mathrm{P}\end{array}$ \\
\hline
\end{tabular}

${ }^{*} P<0.05 ;{ }^{* * *} P<0.001$

the non-bioavailable metal phases buried in the bottom.

On the other hand, precious information seems to arise from the investigation. Any time the sediment is disturbed by dredging or by aerating, an alteration could be induced in the metal toxicity, i.e. transforming them into more soluble compounds which could spread out in the overflowing water (Gambrell et al., 1980; Foerstner et al., 1985; Ludwig and Sherrard, 1989; Hong et al., 1991; Saeki et al., 1993).

Another factor worth considering is related to pollution sources that are clearly identified at specific points on the bay as described by the transect technique of Figs 2-5. Unexpected $\mathrm{Ni}$ and $\mathrm{Mn}$ sources have been discovered in the northern bay area (Transect 1,2 and 3) and old $\mathrm{Cr}$ contamination points in the north-west (Transect 1) have been confirmed.

Table 8. $\mathrm{HNO}_{3}$-extracted phase-correlation matrix among $\mathrm{HNO}_{3}$-extracted metals (anthropogenic

\begin{tabular}{|c|c|c|c|c|c|c|c|c|c|c|}
\hline $\begin{array}{l}\mathrm{Cr} \\
\mathrm{HNO} \\
\mathrm{A}\end{array}$ & $\begin{array}{c}\mathrm{Cu} \\
\mathrm{HNO}_{3} \\
\mathbf{B} \\
\end{array}$ & $\begin{array}{c}\mathrm{Ni} \\
\mathrm{HNO}_{3} \\
\mathrm{C}\end{array}$ & $\begin{array}{c}\mathrm{Pb} \\
\mathrm{HNO}_{3} \\
\mathrm{D} \\
\end{array}$ & $\begin{array}{c}\mathrm{Zn} \\
\mathrm{HNO}_{3} \\
\mathrm{E}\end{array}$ & $\begin{array}{c}\mathrm{Fe} \\
\mathrm{HNO}_{3} \\
\mathrm{~F} \\
\end{array}$ & $\begin{array}{c}\mathrm{Mn} \\
\mathrm{HNO}_{3} \\
\mathrm{G}\end{array}$ & $\begin{array}{c}\mathrm{Fe} \mathrm{b} \\
\mathrm{HNO}_{3} \\
\mathrm{HF} \\
\mathrm{H}\end{array}$ & $\begin{array}{c}\mathrm{Mn} \mathrm{b} \\
\mathrm{HNO}_{3} \\
\mathrm{HF} \\
\mathrm{I}\end{array}$ & $\begin{array}{c}\text { VS } \\
\mathrm{J}\end{array}$ & \\
\hline \multirow[t]{9}{*}{1.00} & 0.16 & 0.20 & 0.20 & 0.07 & $\begin{array}{c}0.34 \\
*\end{array}$ & $\underset{*}{0.35}$ & 0.15 & 0.22 & 0.27 & A \\
\hline & 1.00 & $\begin{array}{c}0.05 \\
*\end{array}$ & $\begin{array}{l}0.78 \\
* * *\end{array}$ & $\begin{array}{l}0.81 \\
* * * *\end{array}$ & $\begin{array}{l}0.55 \\
* * * *\end{array}$ & -0.08 & 0.12 & -0.10 & -0.12 & B \\
\hline & & 1.00 & -0.02 & 0.00 & $\begin{array}{c}0.44 \\
*\end{array}$ & $\begin{array}{c}0.44 \\
*\end{array}$ & $\begin{array}{c}0.39 \\
*\end{array}$ & $\underset{*}{0.33}$ & 0.11 & $\mathrm{C}$ \\
\hline & & & 1.00 & $\begin{array}{l}0.94 \\
* * *\end{array}$ & $\begin{array}{c}0.54 \\
*\end{array}$ & -0.10 & 0.10 & -0.09 & 0.11 & D \\
\hline & & & & 1.00 & $\begin{array}{c}0.48 \\
*\end{array}$ & -0.21 & 0.05 & -0.14 & 0.01 & E \\
\hline & & & & & 1.00 & 0.48 & $\begin{array}{l}0.54 \\
* * *\end{array}$ & $\begin{array}{c}0.40 \\
*\end{array}$ & -0.05 & $\mathbf{F}$ \\
\hline & & & & & & 1.00 & 0.33 & $\begin{array}{l}0.61 \\
* * *\end{array}$ & 0.02 & $G$ \\
\hline & & & & & & & 1.00 & $\begin{array}{l}0.68 \\
* * *\end{array}$ & -0.04 & $\mathbf{H}$ \\
\hline & & & & & & & & 1.00 & $\begin{array}{l}0.02 \\
1.00 \\
\end{array}$ & I \\
\hline
\end{tabular}


A new unexpected $\mathrm{Cr}$ pollution source appears in the central basin (Transect 4) in the form, however, of NBAP. Finally, $\mathrm{Cu}$ pollution in the central bay (Transect 5) and the strong influence of the Rio de Janeiro town with industrial discharges rich in $\mathrm{Zn}$ (Transects 4, 5, and 6) and $\mathrm{Pb}$ (Transects 4 and 5) have been clearly demonstrated.

Acknowledgements - This work was partially funded by C.N.R. (Consiglio Nazionale delle Ricerche, Rome, Italy) and by C.N.Pq (Conselho Nacional de Pesquisa, Brasilia, Brazil).

\section{REFERENCES}

Belzile N., De Vitre R. R. and Tessier A. (1989) Chemistry of $\mathrm{As}(\mathrm{V}) / \mathrm{As}(\mathrm{III})$ and iron oxihydroxides in natural lacustrine sediments. Proc. Int. Conf. Heavy Metals in the Environment 1, pp. 512-515.

Butler J. N. (1964) Ionic Equilibria-A Mathematical Approach. Addison-Wesley, Reading, MA.

Chapman P. M. (1989) Current approach to developing sediment quality criteria. Environ. Toxicol. Chem. 8, 589-599.

Chapman P. M., Paine M. D., Arthur A. D. and Taylor L. A. (1996) A Triad study of sediments quality associated with a major, relatively untreated marine sewage discharge. Mar. Pollut. Bull. 1, 47-64.

Chen Y. K., Gupta S. K., Sycip A. Z., Lu J. C. S., Knezevic $M$. and Choi W. W. (1976) Research study on the effect of dispersion, settling, and resedimentation on migration of chemical constituents during open-water disposal of dredged materials. Dredged Material Research Program Rep. D-76-1. Environ. Effects Lab., US Army Engineer Waterways Experimental Station.

Chester R. and Hughes M. J. (1967) A chemical technique for the separation of Fe-Mn minerals, carbonate minerals and adsorbed trace elements from pelagic sediments. Chem. Geol. 2, 249-262.

De Luca Rebello A., Hanekel W., Moreira I., Santelli R. and Schroeder F. (1986) The fate of heavy metals in an estuarine tropical system. Mar. Chem. 18, 215-225.

De Souza C. M. M., Pestana M. H. D. and Drude de Lacerda L. (1986) Geochemical partitioning of heavy metals in sediments of three estuaries along the coastal of Rio de Janeiro (Brazil). Sci. Total Environ. 58, 63-72.

DiToro D. M., Mahony D. J., Hansen D. J., Scott K. J. K., Carlson A. R. and Ankley G. T. (1992) Acid volatile sulfide predicts the acute toxicity of cadmium and nickel in sediments. Environ. Sci. Technol. 26, 96-101.

Fernex F., Février G. and Benaim J. (1989) Metal accumulation in mediterranean deep sea sediments. Proc. Int. Conf. Heary Metals in the Environment 2, pp. 428-431.

Foerstner U. and Wittmann G. T. W. (1981) Metal Pollution in the Aquatic Environment. Springer Verlag, New York.

Foerstner U., Ahlef W., Calmano W. and Kersten M. (1985) Mobility of heavy metals in dredged materials-upland vs marine disposal. Proc. Int. Conf. Heavy Metals in the Environment Athens (1985) 10-13 Sept.

Gambrell R. P., Katlid R. A. and Patrick W. H. Jr (1980) Chemical availability of mercury, lead and zinc in mobile bay sediment suspensions as affected by $\mathrm{pH}$ and oxidation-reduction conditions. Environ. Sci. Technol. 14, 431-436.

Hong J., Calmano W., Wallmann K., Petersen W., Schroeder F., Knauth D. H. and Foerstner U. (1991) Change in $\mathrm{pH}$ and release of heavy metals in the polluted sediments of Hamburg-harbour and the downstream Elbe during oxidation. Proc. Int. Conf. Heavy Metals in the Environment 1, pp. 330-333.
Horowitz A. J., Elrick K. A. and Hooper R. P. (1989) The prediction of aquatic sediment-associated trace element concentrations using readily obtainable geochemical factors. Proc. Int. Conf. Heavy Metals in the Environment pp. 493-496.

Jonkers D. A. and Everts J. W. (1992) Seaworthy. Derivation of micropollutant risk levels for the North Sea and Wadden Sea. Report nr. 1992/3. Ministry of Housing, Physical Planning and Environment (VROM), The Hague, Netherlands.

Ludwig D. D. and Sherrard J. H. (1989) Heavy metals release at dredging sites. Proc. Int. Conf. Heavy Metals in the Environment 1, pp. 628-631.

Marabini F., Perin G., Traverso P. and Wagener A. (1994) Heavy metals geochemical speciation in the sediments of Guanabara Bay. Proc. IAS 94-14th International Sedimentological Contress-RECIFE (Br) 21-26 Aug. pp. 210-214.

Moreira I. and Godoy J. M. (1988) Preliminary studies of the chronological development of pollution in Guanabara bay, Brazil. Proceeding of Environmental Contamination 3th Int. Confer. pp. 344-346.

Oakley S.M., Nelson P. O. and Williamson K. J. (1981) Model of trace-metal partitioning in marine sediments. Environ. Sci. Technol. 15, 474-480.

Ontario Ministry of Environment (1988) Guidelines for the Management of Dredged Material, Toronto (Ontario).

Perin G., Dotta L. and Craboledda L. (1986) X-ray diffraction technique for the determination of the heavy metal speciation in the sediments. Proc. 3rd. Conf. "Applicazioni Industriali delle Tecniche a Raggi X: Diffrazione e Fluorescenza"-Padua University-Bressanone 18-20 Marzo 1986, pp. 20-36.

Perin G., Traverso P., Scotto S. and Rebello Wagener A. (1993) Heavy metal pollution in the sediments of Guanabara Bay (Rio de Janeiro-Brazil). Preliminary metal speciation and MIBA (Metal Immediate Bio-availability) determination. Proc. Int. Symp. Perspectives for Environmental Geochemistry in Tropical CountriesNiteroi RJ Brazil, Nov. 29-Dec. 31.

Pulford I. D. and Bakhsh A. (1989) Uptake of zinc by soil: adsorption or precipitation? Proc. Int. Conf. Heavy Metals in the Environment 2, pp. 193-196.

Rego V. S., Pfeiffer W. C., Barcellos C. C., Rezende C. E., Malm O. and Soura C. M. M. (1993) Heavy metal transport in the Acari-Sao Joao de Meriti river system, Brazil. Environ. Technol. 14, 167-174.

Rubio R., Lopez-Sanchez J. F. and Rauret G. (1993) Trace metal partitioning in sediments: a common sequential extraction procedure. Verh. Internat. Verein. Limnol. 25, $1147-1149$.

Saeki K., Okazaki M. and Matsumoto S. (1993) The chemical phase changes in heavy metals with drying and oxidation of the lake sediments. Wat. Res. 27, 1243-1251.

Sager M. (1989) The speciation of heavy metals in river sediments found by sequential leaching methods. Proc. Int. Conf. Heavy Metals in the Environment 1, pp. 213-216.

Schnitzer M. and Khan S. U. (1972) Humic Substances in the Environment. Marcel Dekker, New York.

Schoer J. (1985) Iron-oxi-hydroxides and their significance to the behavior of heavy metals in estuaries. Proc. Int. Conf. Heavy Metals in the Environment 1, pp. 384-388.

Schwarzenbach R. P., Gschwend P. M. and Imboen D. M. (1993) Environmental Organic Chemistry. Wiley-Interscience.

Stamoulis S., Gibbs R. J. and Menon M. G. (1996) Geochemical phases of metals in Hudson River estuary sediments. Environ. Internat. 22, 185-194.

Takamatsu T., Kawashima M. and Koyama M. (1985) The role of $\mathrm{Mn}^{2+}$ rich hydrous manganese oxide in the 
accumulation of arsenic in lake sediments. Wat. Res. 19, 1029-1032.

Tessier A., Campbell P. G. C. and Bisson $M$. (1979) Sequential extraction procedure for the speciation of particulate trace metals. Anal. Chem. 51, 844-851.

Tuin B. J. W. and Tels M. (1990) Extraction kinetics of six heavy metals from contaminated clay soils. Environ. Technol. 11, 541-554.

Webster J. and Ridgway I. (1994) The application of the equilibrium partitioning approach for establishing sediment quality criteria at two UK sea disposal and outfall sites. Mar. Pollut. Bull. 28, 653-661. 